\title{
Characterization of volatile compounds of Albertisia papuana Becc root extracts and cytotoxic activity in breast cancer cell line T47D
}

\author{
Elizabeth BE Kristiani ${ }^{1 \star}$, Laurentius H Nugroho², Sukarti Moeljopawiro ${ }^{2}$ and \\ Sitarina Widyarini ${ }^{3}$
}

${ }_{1}^{1}$ Faculty of Biology,Universitas Kristen Satya Wacana, Salatiga, ${ }^{2}$ Faculty of Biology, Universitas Gadjah Mada, Yogyakarta

${ }^{3}$ Faculty of Veterinary Medicine, Universitas Gadjah Mada, Yogyakarta, Indonesia

${ }^{*}$ For correspondence: Email: betty@staff.uksw.edu; Tel: +62 298 321212; Fax: +62 298321433

\begin{abstract}
Purpose: To evaluate the cytotoxic activity of chloroform and water root extracts of Albertisia papuana Becc. on T47D cell line and identify the volatile compounds of the extracts.

Methods: The plant roots were extracted with chloroform and water using maceration and boiling methods, respectively. The cytotoxicity of the extracts on T47D were determined using 3-(4,5dimethylthiazol-2-yl)-2,5-diphenyltetrazolium bromide (MTT) assay. Doxorubicin was used as reference drug in the cytotoxicity test while Probit analysis was used to calculate the Median Growth Inhibitory Concentration $I C_{50}$ of the extracts. The volatile compounds in the chloroform and water root extracts were analyzed using Gas Chromatography-Mass Spectrophotometry GC-MS.

Results: The $I C_{50}$ of the chloroform and water extracts were $28.0 \pm 6.0$ and $88.0 \pm 5.5 \mu \mathrm{g} / \mathrm{mL}$, respectively whereas that of doxorubicin was $8.5 \pm 0.1 \mu \mathrm{g} / \mathrm{mL}$. GC-MS results showed that there were 46 compounds in the chloroform extract, out of which the five major components are ethyl linoleate (49.68\%), bicyclo (3.3.1) non-2-ene (29.29\%), ethyl palmitate (5.06\%), palmitic acid (3.67\%) and ethyl heptadecanoate (1.57\%). The water extract consisted of three compounds, butanoic acid (15.58 $\%)$; methyl cycloheptane (3.45 \%), and methyl 2-O-methylpentofuranoside (80.96 \%).

Conclusion: The chloroform root extract of $A$. papuana Becc. had a fairly potent anticancer activity against breast cancer cells and may be further developed as an anticancer agent. Its major components were fatty acids and fatty acid esters.
\end{abstract}

Keywords: Albertisia papuana Becc., Cytotoxicity, Breast cancer, T47D cell lines, Methyl 2-Omethylpentofuranoside

\begin{abstract}
Tropical Journal of Pharmaceutical Research is indexed by Science Citation Index (SciSearch), Scopus, International Pharmaceutical Abstract, Chemical Abstracts, Embase, Index Copernicus, EBSCO, African Index Medicus, JournalSeek, Journal Citation Reports/Science Edition, Directory of Open Access Journals (DOAJ), African Journal Online, Bioline International, Open-J-Gate and Pharmacy Abstracts
\end{abstract}

\section{INTRODUCTION}

Cancer is considered to be the most killer disease in the world and has become a serious problem for the society, both in the developed countries and developing countries. The ineffectiveness of cancer treatment and side effects from the use of current cancer drugs have encouraged the search of alternative cancer drugs from natural products. Many studies have been carried out to obtain new alternative drugs for cancer treatment. Plants which usually used as traditional medicines have been exploited as a source of active compounds with anticancer activity $[1,2]$.

Albertisia papuana Becc., from the family of Menispermaceae, is recognized as a traditional 
medicinal plant in Sumatra and Kalimantan, Indonesia [3]. Dayak, a tribe in Kalimantan, usually use the root of $A$. papuana Becc. for cancer treatment by boiling it. This plant demonstrated cytotoxic activity on HeLa cell [4]. Some plants from the genus of Albertisia also showed many pharmacological activities. Albertisia delagoensis showed anti-plasmodium and cytotoxic activities on breast cancer, blood cancer, and kidney. It contained alkaloid as bioactive compound [5]. Alkaloid from A. vilosa had antibacterial, antifungal, anti-plasmodium, and cytotoxic activities [6]. Alcoholic extract of $A$. laurifolia had antitumor activity [7].

Based on these reports, A. papuana Becc. could be a potential source in the discovery of bioactive compound for anticancer. Most of the active compounds were alkaloids. In this study, we evaluated the cytotoxic activity of the chloroform and water extracts of $A$. papuana Becc. root on T47D cell lines using MTT assay and identified the volatile compounds which might be the active compounds for anticancer activity. The volatile chemical contents were identified using GC-MS analysis.

\section{EXPERIMENTAL}

\section{Materials}

Albertisia papuana Becc was collected from Dayak, East Kalimantan, Indonesia in April 2014. The plant was identified by Dr. Joeni Setijo Rahajoe, a taxonomist of Herbarium Bogoriense, Biology Research Center, Bogor, Indonesia. A voucher specimen (No. 001/2014/FBUKSW/KHT) was deposited in the herbarium of Laboratory of Primary Biology, Faculty of Biology, Universitas Kristen Satya Wacana, Salatiga, Indonesia. T47D cell line was obtained from Parasitology Laboratory, Faculty of Medicine, Universitas Gadjah Mada, Yogyakarta, Indonesia.

\section{Preparation of root extract of $A$. papuana Becc.}

The roots of about $50 \mathrm{~cm}$ in height of $A$. papuana plants were cleaned using tap water and cut into small pieces. The sample was air-dried for at least a week then dried in an oven at $40{ }^{\circ} \mathrm{C}$ for 5 h. The dried root was ground using a blender (Philip HR1538). The chloroform root extract (CE) was macerated using chloroform $(1: 5 \mathrm{w} / \mathrm{v})$ and then soaked for $24 \mathrm{~h}$. This procedure was repeated four times until the resultant supernatant became clear. The water root extract
(WE) was prepared by the boiling method. The powdered sample was boiled with water $(1: 5 \mathrm{w} / \mathrm{v})$ for five minutes. Each extract was filtered and then dried in a rotary evaporator (Rotavapor R114 Buchi) under vacuum (Eyela A-1000S) at 40 ${ }^{\circ} \mathrm{C}$. The crude extracts were stored at $4{ }^{\circ} \mathrm{C}$ before use.

\section{Cytotoxicity assay}

The in vitro cytotoxicity of chloroform and water extracts and doxorubicin on T47D were determined using 3-(4,5-dimethylthiazol-2-yl)-2,5diphenyltetrazolium bromide(MTT) assay with a slight modification. We used SDS instead of DMSO to stop the formation of formazan crystal. After that, the plate was incubated overnight without rotation on shaker. Briefly, an aliquot of $100 \mu \mathrm{l}$ cell suspension ( $\pm 1 \times 10^{4}$ T47D cells) was loaded into each well of 96-well plate and incubated for $24 \mathrm{~h}$ at $37^{\circ} \mathrm{C}$ in a $5 \% \mathrm{CO}_{2}$ incubator (Heraeus). The various concentrations of treatments (extracts $0-500 \mu \mathrm{g} / \mathrm{mL}$ and doxorubicin $0-100 \mu \mathrm{g} / \mathrm{mL}$ ) were added to each well and then incubated for $24 \mathrm{~h}$ at the same condition. Each concentration tested was in triplicates. At the end of treatment, the medium was removed and $10 \mu \mathrm{LMTT}$ solution $5 \mathrm{mg} / \mathrm{mL}$ (Sigma) was added. The plate was incubated in the dark for 3 to $4 \mathrm{~h}$. The reaction was stopped by the addition of $100 \mu \mathrm{L} 10 \%$ SDS solution in $0.01 \mathrm{~N} \mathrm{HCl}$ (Sigma) and then incubated overnight at room temperature. The absorbance of each well was measured using ELISA reader (SLT 240 ATC) at $595 \mathrm{~nm}$. IC I0 $_{50}$ values (mean \pm SD) were calculated using Probit analysis (SPSS 16.0 for Windows).

\section{Identification of chemical compounds}

The chemical compounds of extracts were analyzed by GC-MS(Agilent GC 6890N 5975B MSD).The capillary column was Agilent 19091S433 model, HP-5MS $5 \%$ Phenyl Methyl Siloxane. The oven temperature was programmed as follows: initial temperature at $100{ }^{\circ} \mathrm{C}$, initial time for $1.00 \mathrm{~min}$, final temperature at $300{ }^{\circ} \mathrm{C}$ for $10.0 \mathrm{~min}$. The conditions of front inlet mode splitless were as follows: initial temperature at $300{ }^{\circ} \mathrm{C}$, pressure was $10.45 \mathrm{psi}$ for $\mathrm{CE}$ and 9.32 psi for WE, purge flow was 50.0 $\mathrm{ml} / \mathrm{min}$, purge time for $0.0 \mathrm{~min}$, total flow 53.8 $\mathrm{ml} / \mathrm{min}$, saver flow for $20.0 \mathrm{ml} / \mathrm{min}$, saver time was $2.0 \mathrm{~min}$, and carrier gas was Helium. The sample was dissolved in pure ethanol and injected using a split technique. Identification of components in sample used Wiley7Nist05.L database. 


\section{RESULTS}

The cytotoxic activity of both extracts on T47D cell lines are shown in Table 1 . The cytotoxicity of $\mathrm{CE}\left(\mathrm{IC}_{50}, 28.0 \mu \mathrm{g} / \mathrm{mL}\right)$ was three-fold higher than that of WE $\left(\mathrm{IC}_{50}, 88.0 \mu \mathrm{g} / \mathrm{mL}\right)$. Both extracts were less cytotoxic than doxorubicin hydrochloride $\left(\mathrm{IC}_{50}, 8.5 \mu \mathrm{g} / \mathrm{mL}\right)$.

Based on the GC-MS chromatogram, there were forty-six compounds in the chloroform root extract of $A$. papuana Becc. (Table 2). The five major components of this extract were ethyl linoleate $(49.68 \%)$, bicyclo (3.3.1) non-2-ene (29.29\%), ethyl palmitate (5.06\%), palmitic acid $(3.67 \%)$, ethyl heptadecanoate $(1.57 \%)$. The other components had a relative concentration less than $1 \%$. The GC-MS chromatograms of water root extract of $A$. papuana Becc. consisted of three compounds (Table 3 ). These were methyl 2-O-methylpentofuranoside (80.98\%), butanoic acid (15.58\%), and methyl cycloheptane (3.45\%).

\section{DISCUSSION}

Natural products are considered as potential sources for drugs in several human diseases including cancer [12]. Many anticancer agents are plant-based compounds. Albertisia papuana is one of the endogenous plants in Dayak, East Kalimantan. Dayak people usually use $A$. papuana Becc for cancer treatment by boiling the root of the plant using water. In this study, the difference in solvents caused the difference of yield rendemen and cytotoxic activity of the extracts. The cytotoxic activity of the water extract was three time lower than the chloroform extract. Some alkaloids have been reported as heat labile compounds, so it is very possible that the alkaloids in the water extract were decomposed during the water extraction process [9].

In vitro cytotoxicity screening is often used to select the potential medicinal properties of a matter. This method was used to determine the inhibition of the growth of cells caused by an anticancer agent. According to The National Cancer Institute ( $\mathrm{NCl}$ ) USA, the $\mathrm{IC}_{50}$ values of 30 $\mu \mathrm{g} / \mathrm{mL}$ is the upper limit of the crude extract which is qualified for further purification [12], so the chloroform root extract was promising for further purification because its $\mathrm{IC}_{50}$ value was $28.0 \mathrm{mg} / \mathrm{mL}$. On other hand, to extract the root of the plant by boiling with water was not recommended. It showed that the extraction method is one of the crucial steps to obtain the active compound which have medicinal properties.

The medicinal properties of plants are caused by the presence of active compounds of therapeutic value. The active compounds can be extracted from plants by an extraction method with certain solvents. The traditional medicines usually use water as a solvent, but modern medicines use various organic solvents in order to exploit the various compounds in herbal medicines [10]. The use of chloroform would extract non polar compounds, whereas water would extract polar compounds. The majority of compounds from the chloroform extract were organic acids, a long chain of saturated and an unsaturated hydrocarbon, or triterpene and sesquiterpene [11-14].

Based on the GC-MS chromatogram, it seems that the anticancer activity of chloroform root extract of $A$. papuana Becc. might be because of the action of the major compounds of this extract such asethyl linoleate, bicyclo (3.3.1) non-2-ene, ethyl palmitate, palmitic acid, and ethyl heptadecanoate. It has been reported that some of these compounds were also found in chloroform leaf extract of Finlaysonia obovata [12] and Acacia nilotica L [11]. Ethyl linoleate is a derivative of linoleic acid (LA). Various studies have reported that has biological beneficial effects, including anticancer activity. LA inhibits the initiation, promotion, and progression phases in mammary tumors [14].In addition, LA showed anticancer activity [16], especially by its antiproliferative activity [17] and by inducing apoptosis in breast cancer cells [18].LA was demonstrated to not only inhibit the growth of hepatoma cell but also induce apoptosis in colorectal cell line $[19,20]$. A study of human leukemic cells MOLT-4 showed that palmitic acid inhibited DNA topoisomerase I and induced apoptosis [20], however in human lung adenocarcinoma cell line A549,

Table 1: Cytotoxicity of $A$. papuana Becc. chloroform and water root extracts on T47D cell line

\begin{tabular}{llll}
\hline Plant (part) & Solvent & Code & $\mathbf{I C}_{50}(\boldsymbol{\mu g} / \mathbf{m L})$ \\
\hline Root & Chloroform & CE & $28.0 \pm 6.0$ \\
Root & Water & WE & $88.0 \pm 5.5$ \\
- & - & Doxorubicin $(D X)$ & $8.5 \pm 0.1$ \\
\hline
\end{tabular}


Table 2: Compounds in chloroform root extract of $A$. papuana Becc analyzed using GC-MS

\begin{tabular}{|c|c|c|c|c|c|}
\hline No. & $\begin{array}{l}\text { Retention } \\
\text { time }\end{array}$ & Compound & Formula & $\begin{array}{c}\text { Mol } \\
\text { wt }\end{array}$ & $\begin{array}{c}\text { Area } \\
(\%)\end{array}$ \\
\hline 1 & 5.949 & 7-Methyl-2-decene & $\mathrm{C}_{11} \mathrm{H}_{22}$ & 154 & 0.17 \\
\hline 2 & 6.053 & 2-Acetylcyclopentanone & $\mathrm{C}_{7} \mathrm{H}_{10} \mathrm{O}_{2}$ & 154 & 0.15 \\
\hline 3 & 6.164 & 4-Methyl-2-decene & $\mathrm{C}_{11} \mathrm{H}_{22}$ & 128 & 0.26 \\
\hline 4 & 8.069 & 2,3,5,8-Tetramethyldecane & $\mathrm{C}_{14} \mathrm{H}_{30}$ & 198 & 0.07 \\
\hline 5 & 8.179 & $\begin{array}{l}\text { 2,6-Di-tert-butyl-4-methylene-2,5-cyclo } \\
\text { one }\end{array}$ & $\mathrm{C}_{15} \mathrm{H}_{22} \mathrm{O}$ & 218 & 0.06 \\
\hline 6 & 8.589 & 2,4-Bis(1,1-Dimethylethyl)-phenol & $\mathrm{C}_{14} \mathrm{H}_{22} \mathrm{O}$ & 206 & 0.42 \\
\hline 7 & 8.706 & 1-Cyclopentylethanone & $\mathrm{C}_{7} \mathrm{H}_{12} \mathrm{O}$ & 112 & 0.11 \\
\hline 8 & 9.784 & 1-(Dodecyloxy)ethanol & $\mathrm{C}_{14} \mathrm{H}_{30} \mathrm{O}_{2}$ & 230 & 0.10 \\
\hline 9 & 8.920 & 1,2,4-Trimethylcyclohexane & $\mathrm{C}_{9} \mathrm{H}_{18}$ & 126 & 0.13 \\
\hline 10 & 9.044 & $1,1^{\prime}-$ Oxybis decane & $\mathrm{C}_{20} \mathrm{H}_{42} \mathrm{O}$ & 298 & 0.11 \\
\hline 11 & 10.578 & n-Heptadecane & $\mathrm{C}_{17} \mathrm{H}_{36}$ & 240 & 0.10 \\
\hline 12 & 10.643 & $2,6,11,15$-Tetramethyl hexadecane & $\mathrm{C}_{20} \mathrm{H}_{42}$ & 282 & 0.10 \\
\hline 13 & 11.039 & 1,3,5-Trimethylcyclohexane & $\mathrm{C}_{9} \mathrm{H}_{18}$ & 126 & 0.07 \\
\hline 14 & 11.215 & Tetratetracontane & $\mathrm{C}_{44} \mathrm{H}_{90}$ & 619 & 0.25 \\
\hline 15 & 11.345 & 1,2,4-Trimethylcyclohexane & $\mathrm{C}_{9} \mathrm{H}_{18}$ & 126 & 0.36 \\
\hline 16 & 11.429 & 1-Bromohexadecane & $\mathrm{C}_{16} \mathrm{H}_{33} \mathrm{Br}$ & 305 & 0.18 \\
\hline 17 & 11.657 & n-Octadecane & $\mathrm{C}_{18} \mathrm{H}_{38}$ & 254 & 0.36 \\
\hline 18 & 12.684 & Nonadecane & $\mathrm{C}_{19} \mathrm{H}_{40}$ & 268 & 0.25 \\
\hline 19 & 13.250 & Hexadecenoic acid & $\mathrm{C}_{16} \mathrm{H}_{30} \mathrm{O}$ & 254 & 0.44 \\
\hline 20 & 13.497 & Palmitic acid & $\mathrm{C}_{16} \mathrm{H}_{32} \mathrm{O}_{2}$ & 256 & 3.67 \\
\hline 21 & 13.653 & Ethyl palmitate & $\mathrm{C}_{18} \mathrm{H}_{36} \mathrm{O}_{2}$ & 284 & 5.06 \\
\hline 22 & 13.822 & Diethylmethylborane & $\mathrm{C}_{5} \mathrm{H}_{13} \mathrm{~B}$ & 84 & 0.13 \\
\hline 23 & 14.394 & Heptadecanoic acid & $\mathrm{C}_{17} \mathrm{H}_{34} \mathrm{O}_{2}$ & 270 & 0.35 \\
\hline 24 & 14.576 & Ethyl heptadecanoate & $\mathrm{C}_{19} \mathrm{H}_{38} \mathrm{O}_{2}$ & 298 & 0.58 \\
\hline 25 & 15.323 & Ethyl linoleate & $\mathrm{C}_{20} \mathrm{H}_{36} \mathrm{O}_{2}$ & 308 & 49.68 \\
\hline 26 & 15.570 & Bicyclo (3.3.1) non-2-ene & $\mathrm{C}_{9} \mathrm{H}_{14}$ & 122 & 29.29 \\
\hline 27 & 15.830 & (Cyclohex-2-enyl)acetic acid & $\mathrm{C}_{8} \mathrm{H}_{12} \mathrm{O}_{2}$ & 140 & 0.36 \\
\hline 28 & 15.882 & Methyl-6-octadecynoate & $\mathrm{C}_{19} \mathrm{H}_{36} \mathrm{O}_{2}$ & 296 & 0.43 \\
\hline 29 & 15.999 & (Cyclohex-2-enyl) acetic acid & $\mathrm{C}_{8} \mathrm{H}_{12} \mathrm{O}_{2}$ & 140 & 0.42 \\
\hline 30 & 16.136 & 2-Methyl-Z,Z-3,13-octadecadienol & $\mathrm{C}_{19} \mathrm{H}_{36} \mathrm{O}$ & 280 & 0.25 \\
\hline 31 & 16.357 & Ethyl nonadecanoate & $\mathrm{C}_{21} \mathrm{H}_{42} \mathrm{O}_{2}$ & 326 & 0.55 \\
\hline 32 & 16.981 & 2-Methylene-cyclododecanone & $\mathrm{C}_{13} \mathrm{H}_{22} \mathrm{O}$ & 194 & 0.80 \\
\hline 33 & 17.033 & Tetradec-13-en-11-yn-1-ol & $\mathrm{C}_{14} \mathrm{H}_{24} \mathrm{O}$ & 208 & 0.52 \\
\hline 34 & 17.189 & Ethyl heptadecanoate & $\mathrm{C}_{19} \mathrm{H}_{38} \mathrm{O}_{2}$ & 298 & 1.57 \\
\hline 35 & 17.351 & $9,12,15$-Octadecatrienoic acid & $\mathrm{C}_{18} \mathrm{H}_{30} \mathrm{O}_{2}$ & 278 & 0.39 \\
\hline 36 & 17.644 & 2-Methyl-Z,Z-3,13-octadecadienol & $\mathrm{C}_{19} \mathrm{H}_{36} \mathrm{O}$ & 280 & 0.18 \\
\hline 37 & 17.988 & 1-Methyltridecyl methoxyacetate & $\mathrm{C}_{17} \mathrm{H}_{34} \mathrm{O}_{3}$ & 286 & 0.21 \\
\hline 38 & 18.463 & $\begin{array}{l}\text { 1,2-Benzenedicarboxylic acid, mono (2-ethylhexyl) } \\
\text { ester }\end{array}$ & $\mathrm{C}_{16} \mathrm{H}_{22} \mathrm{O}_{4}$ & 278 & 0.13 \\
\hline 39 & 18.749 & 1-Chlorooctadecane & $\mathrm{C}_{18} \mathrm{H}_{37} \mathrm{Cl}$ & 288 & 0.22 \\
\hline 40 & 19.484 & Eicosane & $\mathrm{C}_{20} \mathrm{H}_{42}$ & 282 & 0.16 \\
\hline 41 & 20.199 & Ethyl palmitate & $\mathrm{C}_{18} \mathrm{H}_{36} \mathrm{O}_{2}$ & 284 & 0.29 \\
\hline 42 & 20.888 & Ethyl heptadecanoate & $\mathrm{C}_{19} \mathrm{H}_{38} \mathrm{O}_{2}$ & 298 & 0.22 \\
\hline 43 & 21.577 & 7h-dibenzo-c,g-carbazole & $\mathrm{C}_{20} \mathrm{H}_{13} \mathrm{~N}$ & 281 & 0.20 \\
\hline 44 & 22.006 & $\mathrm{~N}$-(3-methoxyphenyl)-2,2-dimethylpropanamide & $\mathrm{C}_{12} \mathrm{H}_{17} \mathrm{NO}_{2}$ & 207 & 0.21 \\
\hline 45 & 24.398 & Beta-stigmasterol & $\mathrm{C}_{29} \mathrm{H}_{48} \mathrm{O}$ & 412 & 0.18 \\
\hline 46 & 25.094 & Gamma-sitosterol & $\mathrm{C}_{29} \mathrm{H}_{50} \mathrm{O}$ & 414 & 0.19 \\
\hline
\end{tabular}

Table 3: Compounds in water root extract of $A$. papuana Becc. analyzed using GC-MS

\begin{tabular}{lllccc}
\hline No. & $\begin{array}{l}\text { Retention } \\
\text { time }\end{array}$ & Compound & Formula & $\begin{array}{c}\text { Mol } \\
\text { wt }\end{array}$ & $\begin{array}{c}\text { Content } \\
(\%)\end{array}$ \\
\hline 1 & 14.524 & Butanoic acid & $\mathrm{C}_{4} \mathrm{H}_{8} \mathrm{O}_{2}$ & 88 & 15.58 \\
2 & 14.758 & Methylcycloheptane & $\mathrm{C}_{8} \mathrm{H}_{6}$ & 112 & 3.45 \\
3 & 16.513 & Methyl 2-O-methylpentofuranoside & $\mathrm{C}_{7} \mathrm{H}_{114} \mathrm{O}_{5}$ & 178 & 80.96 \\
\hline
\end{tabular}

palmitic acid only inhibited DNA topoisomerase I without inducing apoptosis [21].

Palmitic acid, an active compound from Marthasterias glacialis L. showed apoptotic activity in neuroblastoma cell line by a ceramideindependent mechanism [22].In this study, a minor compound of water root extract of $A$. papuana Becc., butanoic acid was reported to have anticancer activity. Previous studies 
demonstrate that butyric acid induced apoptosis in some cancers cells [23]. According to this study, the volatile compounds in both of the extracts were had anticancer activity. The chloroform extract contains forty six compounds, some of which have been known to have cytotoxic activity. While, water extract contains three compounds and only one compound has cytotoxic activity. Therefore, the water extract was less toxic than the chloroform extract.

\section{CONCLUSION}

The chloroform root extract of $A$. papuana Becc. has a fairly potent anticancer activity with some promise. Further purification and isolation of the bioactive anticancer compounds may yield a more cytotoxic agent. The major components are fatty acids and fatty acid esters. The water root extract of $A$. papuana which contains butanoic acid also has some anticancer activity.

\section{ACKNOWLEDGEMENT}

The authors appreciate Ministry of Education and Culture of Indonesia for providing BPPS scholarship in Faculty of Biology, Universitas Gadjah Mada, Yogyakarta, Indonesia.

\section{CONFLICT OF INTEREST}

No conflict of interest associated with this work.

\section{CONTRIBUTION OF AUTHORS}

We declare that this work was done by the authors named in this article and all liabilities pertaining to claims relating to the content of this article will be borne by the authors.

\section{REFERENCES}

1. Divya MK, Sheema D, Achuthan CR, Babu TD. Cytotoxic and antitumor effects of Tribulus terrestris $L$. fruit methanolic extract. Journal of Pharmacog Phytochem 2014; 3(2):1-4.

2. Fadeyi SA, Fadeyi OO, Adejumo AA, Okoro C, Myles EL. In vitro Anticancer Screening of 24 Locally Used Nigerian Medicinal Plants. BMC Complem Alt Med 2013; 13: 79.

3. Lusiana $H$, Irawadi TT, Suprapto $H$. Uji antiplasmodium senyawa alkaloid dari Albertisia papuana Becc. Seminar Nasional Kimia Terapan Indonesia 2013; 1:75-78.

4. Angerhofer $C K$, Guinaudeau $H$, Wongpanich V, Pezzuto JM, Cordell GA. Antiplasmodial and cytotoxic activity of natural bisbenzylisoquinoline alkaloids. J Nat Prod 1999; 62:59-66.
5. Wet $H D$, Fouche G, Herden FRV. In vitro cytotoxicity of crude alkaloid extracts of South African Menispremaceae against three cancer cell lines. Afr J Biotechnol 2009; 8(14):3332-3335.

6. Lohombo-Ekombo ML, Okusa PN, Penge O, Kabongo C, Choundary MI, Kasende OE. Antibacterial, antifungal, antiplasmodial, and cytotoxic activities of Albertisia villosa. J Ethnopharmacol 2004; 93(2-3):331-335.

7. Zhi X, Yun W, Pei-Ling Z, Jian-Min M, Ping H. Studies on alkaloids Albertisia laurifola. Acta Bot Sin 1985; 27(6):630-634.

8. Kuete $V$, Wabo HK, Eyong KO, Feussi MT, Wiench $B$, Krusche B, Tane P, Folefoc GN, Efferth T. Anticancer Activities of Six Selected Natural Compounds of Some Cameroonian Medicinal Plants. PLoS ONE 2011; 6(8):17.

9. Kashani HH, Hoseini ES, Nikzad H, Aarabi MH. Pharmacological properties of medicinal herbs by focus on secondary metabolites. Life Sci J 2012; 9(1):509520.

10. Handa SS, Khanuja SPS, Longo G, Rakesh DD. Extraction Technologies for Medicinal and Aromatic Plants. International centre for science and high technology, Trieste, 2008.p21-25.

11. Bai SW, Seasotiya L, Malik A, Bharti P, Dalal S. GC-MS analysis of chloroform extract of Acacia nilotica $L$. leaves. Journal of Pharmacog Phytochem 2014; 2(6):79-82.

12. Mishra PM and Sree A. Antibacterial activity and GCMS analysis of the extract of leaves of Finlaysonia oborvata (A mangrove plant). Asian J Plant Sci 2007; 6(1):168172.

13. Hariprasad PS and Ramakhrisnan N. GC-MS analysis of Rumex vesicarius L. IJDDR 2011; 3(2):256-263.

14. Shirsat MK, Mahatma OP, Umesh SP, Sanjay KB, Dwivedi J.GC-MS analysis of calotropis gigantean linn whole plant chloroform extract. JPBS 2013; 1:26-29.

15. Amarù $D L$, Biondo $P D$ and Field CJ. The Role of Conjugated Linoleic Acid in Breast Cancer Growth and Development. Open Nutraceuticals J2010; 3:30-46.

16. Tanmahasamut P, Liu J, Hendry LB, Sidell N. Conjugated Linoleic Acid Blocks Estrogen Signaling in Human Breast Cancer Cells 1. J. Nutr 2004; 134:674-680.

17. Guidong $H$, Xianfeng $Z$, Yusheng $C$, Yan $C$. Antiproliferative effects of conjugated linoleic acid on human colon adenocarcinoma cell line Caco-2. Asia Pac $J$ Clin Nutr 2007; 16(Suppl 1):432-436.

18. W L-S, Huang Y-W, Liu S, Yan P, Lin YC. Conjugated linoleic acid induces apoptosis through estrogen receptor alpha in human breast tissue. BMC Cancer 2008; 8:208.

19. Lu X, Yu H, Ma Q, Shen S, Das UN. Linoleic acid suppresses colorectal cancer cell growth by inducing oxidant stress and mitochondrial dysfunction. Lipids Health Disease 2010; 9:106.

20. Harada H, Yamashita U, Kurihara H, Fukushi E, Kawabata J, Kamei Y. Antitumor activity of palmitic acid 
found as a selective cytotoxic substance in a marine red alga. Anticancer Res 2002; 22(5):2587-90.

21. Karna S, Lim WB, Kim JS, Kim SW, Zheng H, Bae KH, Cho MS, Oh HK, Kim OS, Choi HR, Kim OJ. C16 Saturated Fatty Acid Induced Autophagy in A549 Cells through Topoisomerase I Inhibition. FNS 2012; 3:12201227.
22. Pereira DM, Correia-da-Silva G, Valentão $P$, Teixeira N, Andrade PB. Palmitic Acid and Ergosta-7,22-dien-3-ol Contribute to the Apoptotic Effect and Cell Cycle Arrest of an Extract from Marthasterias glacialis $L$. in Neuroblastoma Cells. Mar Drugs 2014; 12: 54-68.

23. Singh NO and Lai HC. Synergistic Cytotoxicity of Artemisinin and Sodium Butyrate on Human Cancer Cells. Anticancer Res 2005; 25:4325-4332. 